\title{
Prevalence of parasites in amphipods Diporeia spp. from Lakes Michigan and Huron, USA
}

\author{
Gretchen A. Messick ${ }^{1, *}$, Robin M. Overstreet ${ }^{2}$, Thomas F. Nalepa $^{3}$, Sue Tyler ${ }^{1}$ \\ ${ }^{1}$ NOAA, National Ocean Service, Cooperative Oxford Laboratory, 904 S. Morris Street, Oxford, Maryland 21654, USA \\ ${ }^{2}$ Gulf Coast Research Laboratory, The University of Southern Mississippi, PO Box 7000, Ocean Springs, Mississippi 39566, USA \\ ${ }^{3}$ NOAA, Great Lakes Environmental Research Laboratory, 2205 Commonwealth Boulevard, Ann Arbor, Michigan 48105, USA
}

\begin{abstract}
Amphipods of Diporeia spp. have declined considerably during the last decade in the Great Lakes. We examined the possibility that disease may be affecting these populations. A histological survey assessed the parasites in species of Diporeia within Lakes Huron and Michigan, USA, and the host response to some of them and to unknown factors. Amphipods were found to have an intranuclear inclusion body, and were hosts to a rickettsia-like organism, fungi, a haplosporidian, a microsporidian, epibiotic ciliates, a gregarine, a cestode, acanthocephalans and nodule formations. Epibiotic ciliates were most common (37\% prevalence of infection), but a microsporidian (3.8\%), a rickettsia-like organism (1.6\%), fungi, including a yeast-like organism (1.3\%), worms $(1.3 \%)$, and a haplosporidian $(0.7 \%)$ are likely associated with mortalities or detrimental effects on the host. The role these agents may have played in the decline of Diporeia spp. in the Great Lakes over the last decade is not clear. Interrelationships with the dynamics of various physical and biological factors such as high sedimentation, diminished food supplies, and virulent parasites could synergistically cause the decline in Diporeia spp. populations in Lakes Michigan and Huron.
\end{abstract}

KEY WORDS: Diporeia spp. · Parasites · Amphipods · Freshwater · Rickettsia · Haplosporidian · Microsporidian · Yeast

Resale or republication not permitted without written consent of the publisher

\section{INTRODUCTION}

Amphipod species of Diporeia are found in abundance in northern proglacial lakes of North America. They are benthic detritivores that occur in the top 1 to $2 \mathrm{~cm}$ of sediment and feed on organic material freshly settled from the water column. In turn, amphipods are fed upon by many fish species and are a major foodweb link between pelagic production and upper trophic levels (Gardener et al. 1990). Declines in Diporeia spp. were first observed in Lake Michigan in 1992, 3 yr after the non-indigenous zebra mussel Dreissena polymorpha was first reported in the lake (Nalepa et al. 1998). Diporeia spp. numbers have diminished each subsequent year and have now disappeared from $30 \%$ of the southern Lake Michigan basin. In some locations, Diporeia spp. declined from 10000 to $20000 \mathrm{~m}^{-2}$ to near $0 \mathrm{~m}^{-2}$ in just $6 \mathrm{mo}$, while in other locations, numbers of amphipods declined to 0 over a period of 4 yr. Declines first occurred at shallow sites close to shore, but have subsequently spread to depths of ca. $70 \mathrm{~m}$ (Nalepa et al. 1998, Nalepa unpubl. data). Declines have also occurred in Lakes Erie (Dermott \& Kerec 1997) and Ontario (Lozano et al. 2001). Fish species that relied heavily on Diporeia spp. as a food source, such as lake whitefish Coregonus clupeaformis, bloater Coregonus hoyi and slimy sculpin Cottus cognatus, are declining in abundance or shifting feeding patterns (Pothoven et al. 2001, Hondorp et al. unpubl.). It has been suggested that the decline in Diporeia spp. may be due to the nonindigenous zebra mussel D. polymorpha intercepting the algal diet before it settles to the bottom, thus decreasing the amount available to these amphipods (Nalepa et al. 1998, 2000). However, sampling efforts indicate that sufficient food is still available to support 
the benthic amphipod populations, and that lipid content and body condition (weight per unit length) of Diporeia spp. remain high (Nalepa unpubl. data). Furthermore, rates of decline are greatest in areas with no zebra mussels and with the highest sedimentation rates.

An important factor to consider is whether or not pathogens are playing a significant role in the decline. Epizootic diseases in amphipods have been reported to greatly reduce (Pixell Goodrich 1929) or limit populations (Johnson 1986). Endemic pathogens of amphipods that have been present for years may now be affecting amphipods due to unrecognized new stressors. Alternatively, newly introduced zebra mussels or other sources may harbor non-indigenous organisms that are pathogenic to amphipods in the Great Lakes. To investigate whether or not a pathogen may be influencing the decline in numbers of amphipods, a histological survey of amphipods was conducted. This paper reports characteristics of disease and parasitism in Diporeia spp. from Lakes Michigan and Huron, and compares the prevalence of these findings over a broad spatial and temporal sampling series within these 2 lakes. Our purpose was to survey the prevalence of parasites, to examine host responses, and to determine whether or not infections may influence declines in Diporeia spp.

\section{MATERIALS AND METHODS}

The taxonomy of Diporeia spp. has not been fully defined. One species of amphipod Pontoporeia hoyi was thought to occur in North America until Bousfield (1989) recognized as many as 8 North American species and placed them in a new genus, Diporeia. Five of these species, $D$. hoyi, $D$. kendalli, $D$. brevicornis and 2 that have not yet been named, occur in the Great Lakes. Since the entire population (i.e. all species) has declined to zero over time in some areas, we can assume that declines are not species specific. Due to this consistent decline pattern, and the uncertainty in the taxonomy, this study uses Diporeia spp. and Diporeia to refer to all species of this genus that have been found in the Great Lakes. Nevertheless, specimens in our collection may include what was previously called Pontoporeia affinis and P. hoyi. To assay for temporal variation in disease prevalence, 550 amphipods were randomly subsampled from archived specimens collected during 1986, 1987, and every year between 1992 and 1999. This time-series represents the period before (1986 and 1987) and after the introduction of the zebra mussel Dreissena polymorpha. These amphipods were collected from 3 sites in southeastern Lake Michigan (Fig. 1) during 21 sampling periods and preserved and stored in $5 \%$ buffered formalin.
Presently, Diporeia spp. are rare or no longer present at these sites (Nalepa unpubl. data). To assay for spatial variation in the prevalence of parasites, 1165 amphipods were collected from sediments in July and August 2000 from 85 sites in Lakes Michigan and Huron (Fig. 1). Sediment samples were collected using a Ponar grab and washed on-board through an elutriation device fitted with a $0.5 \mathrm{~mm}$ mesh net (Nalepa et al. 1998). The retained animals were immediately picked from the sample (10 to 20 animals per site) and placed in Bouin's fluid (Howard \& Smith 1983). After 12 to $16 \mathrm{~h}$, animals were transferred to $70 \%$ ethanol. All specimens were sent to the Cooperative Oxford Laboratory, Maryland, for histological analysis.

Preserved amphipods were dehydrated through increasing concentrations of ethanol, infiltrated with paraffin, embedded, sectioned sagittally at 4 to $5 \mu \mathrm{m}$ thickness, and stained in Mayer's hematoxylin and eosin (MHE) (Luna 1968). Selected amphipods were stained with special stains to better elucidate certain parasites (Table 1). Prepared slides were observed with a light microscope and data recorded on host tissue response and the presence of parasites.

Data from amphipods collected from Lakes Michigan and Huron were analyzed using factorial ANOVA techniques (SAS 1999). The analyses tested temporal effects: collection date, year, season, and period before or after the introduction of the zebra mussel as well as spatial effects: lake, north versus south versus Grand Traverse Bay and water depth on the prevalence of host response or parasites. The large number of collec-

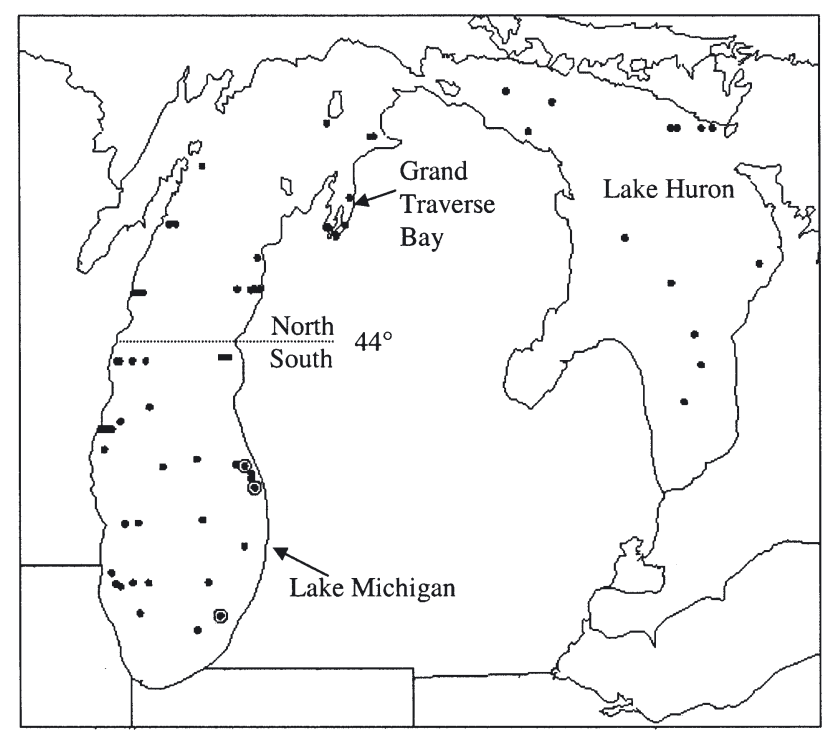

Fig. 1. Location of sampling sites for the complex of species of Diporeia in Lakes Michigan (left) and Huron (right) in 2000. Additional archived specimens were examined from the 3 encircled sites (๑) 
Table 1. Special stains, acronyms, target tissues, stain results and stain references used in study of parasites in Diporeia spp. from Lakes Michigan and Huron

\begin{tabular}{|c|c|c|c|c|}
\hline Stain & Acronym & Target tissues & Stain results & Source \\
\hline $\begin{array}{l}\text { Ziehl-Neelsen and } \\
\text { Harris' hematoxylin }\end{array}$ & AFB & Acid-fast substances & $\begin{array}{l}\text { Basophilic structures: blue; acid-fast } \\
\text { substances, including mature haplosporidians } \\
\text { and acid-fast bacteria: bright red }\end{array}$ & Luna (1968) \\
\hline $\begin{array}{l}\text { Feulgen picro-methyl } \\
\text { blue }\end{array}$ & FPM & $\begin{array}{l}\text { DNA }_{\text {; collagen, }} \\
\text { connective tissue }\end{array}$ & $\begin{array}{l}\text { DNA: red; nucleoli, muscle, acidophilic } \\
\text { substances: yellow; connective tissue: blue; } \\
\text { cytoplasmic protein: green }\end{array}$ & Farley (1969) \\
\hline $\begin{array}{l}\text { Grocott's methenamine } \\
\text { silver }\end{array}$ & GMS & Fungi & $\begin{array}{l}\text { Fungi: delineated in black; mucin: taupe } \\
\text { to dark grey; mycelia inner parts and } \\
\text { hyphae: old rose; background: pale green }\end{array}$ & Luna (1968) \\
\hline Giemsa & Giemsa & General tissue & $\begin{array}{l}\text { Nuclei and basophilic substances: blue; } \\
\text { cytoplasm and acidophilic substances: pink }\end{array}$ & Luna (1968) \\
\hline Periodic acid Schiff & PAS & $\begin{array}{l}\text { Glycogen, fungi, neutral } \\
\text { mucopolysaccharides }\end{array}$ & $\begin{array}{l}\text { Glycogen: magenta; PAS+ substances: pink to } \\
\text { magenta; basophilic substances: blue-black }\end{array}$ & Lillie (1965) \\
\hline $\begin{array}{l}\text { Pierce Van der Kamp } \\
\text { adapted Machiavello stain }\end{array}$ & PVK & Rickettsia-like organisms & Rickettsiae: bright red; background: green & Andersen (1998) \\
\hline Gram for bacteria & Gram & Bacteria & $\begin{array}{l}\text { Nuclei: blue-violet; cytoplasm: shades of light } \\
\text { blue or pale pink; muscle: bright pink; bacteria: blue }\end{array}$ & $\begin{array}{l}\text { Brown \& Hopps } \\
\text { (1973) }\end{array}$ \\
\hline $\begin{array}{l}\text { Mayer's hematoxylin } \\
\text { and eosin }\end{array}$ & MHE & General tissue & $\begin{array}{l}\text { Nuclei and basophilic substances: blue; cytoplasm } \\
\text { and acidophilic substances: pink }\end{array}$ & Luna (1968) \\
\hline
\end{tabular}

tions at numerous stations resulted in reasonable sample sizes, which allowed for estimates of mean prevalence for ANOVA. Observations with missing data were omitted from the statistical analyses and prevalence values were arcsine-root transformed to meet required criteria. Effects were considered significant at $\mathrm{p}<0.05 ; \pm$ indicates the standard error of measurements. For data analyses, amphipods collected before or during 1987 were categorized as having been collected before the introduction of zebra mussels; all others were categorized as collected after the introduction. For analysis, Lake Michigan was divided into north (above $44^{\circ}$ latitude), south (below $44^{\circ}$ latitude) and Grand Traverse Bay. Water depth at all collection sites was divided into 7 categories: <25, 26-50, 51-75, $76-100,101-125,126-150$ and $>150 \mathrm{~m}$. For statistical analysis, nodules were considered a category of host response induced by various species of known and unknown etiological agents. Three different unidentified species of ciliate were grouped within a single category called ciliates. Both categories, ciliates and nodules, consist of more than one species or etiological agent; thus, statistical analysis of these categories is not equivalent with that of individual components. Since amphipod numbers have greatly decreased, we felt it justified to include prevalence data on all the parasites we found rather than focusing solely on the most prevalent parasites, and also to provide baseline data on the relatively large sample number of Diporeia spp. sampled.

\section{RESULTS}

Several parasites and host response to parasites and unknown agents were found in assayed amphipods (Table 2 ; also see Table 2 for definitions to all stain abbreviations from this point). Nodules are the histological manifestation of a host response in which tissue debris or an injurious agent is sequestered within a sheath of differentiated host hemocytes (Fig. 2). Many observed nodules contained obvious parasites within the encapsulating layers of hemocytes (Fig. 2), while others had no discernible parasites. Intranuclear basophilic bodies, often associated with virus infections, caused infected nuclei to be hypertrophied with a thin rim of darkly staining chromatic material (Fig. 3).

Histologically, rickettsia-like infections (Table 2) appeared as basophilic masses of a small intracellular gram-negative bacterium. Infections were confined within the cytoplasm and cells were greatly hyper- 
Table 2. Diporeia spp. Prevalence, tissues infected, staining qualities and host response to parasites found in 1715 amphipods collected from 85 sites within Lakes Michigan and Huron from 1986 to 2000. See Table 1 for definitions of stain acronyms; -: negative; +: positive

\begin{tabular}{|c|c|c|c|c|}
\hline $\begin{array}{l}\text { Condition } \\
\text { agent }\end{array}$ & $\begin{array}{l}\text { Prevalence } \\
\%\end{array}$ & $\begin{array}{l}\text { Tissues } \\
\text { infected }\end{array}$ & $\begin{array}{l}\text { Staining } \\
\text { qualities }\end{array}$ & $\begin{array}{l}\text { Host } \\
\text { response }\end{array}$ \\
\hline Nodules & 6.9 & Hemal sinuses and connective tissues & MHE: basophilic or brownish & Yes \\
\hline $\begin{array}{l}\text { Intranuclear basophilic } \\
\text { bodies }\end{array}$ & 0.2 & Cuticular and gill epithelial cells & MHE: basophilic, FPM: faintly+ & No \\
\hline Rickettsia-like organism & 1.6 & $\begin{array}{l}\text { Lipid cells, epithelial cells of } \\
\text { digestive ceca, or hemocytes }\end{array}$ & $\begin{array}{l}\text { MHE: basophilic, gram-, FPM+, Giemsa: pink, } \\
\text { PVK: bright red }\end{array}$ & Yes \\
\hline $\begin{array}{l}\text { Yeast-like organism } \\
2.2 \times 5.0 \mu \mathrm{m}\end{array}$ & 0.5 & Hemal sinuses & MHE: basophilic, GMS+, PAS+, AFB- & Yes \\
\hline Yeast $24 \times 2.5 \mu \mathrm{m}$ & 0.06 & Hemal sinuses & $\begin{array}{l}\text { MHE: faintly basophilic, GMS+, PAS+, AFB-, } \\
\text { Feulgen-, Gram- }\end{array}$ & Yes \\
\hline Fungus $1.8 \pm 0.30 \mu \mathrm{m}$ diameter & 0.06 & Hemal sinuses and connective tissues & MHE: basophilic, GMS+, PAS+ & Saprophytic \\
\hline $\begin{array}{l}\text { Haplosporidian } \\
8.1 \times 6.1 \mu \mathrm{m} \text { spores }\end{array}$ & 0.7 & Hemal sinuses & MHE: basophilic, GMS+, AFB+, PAS+ & $?$ \\
\hline Microsporidian & 3.8 & Muscle & MHE: basophilic, AFB+, Gram +, Giemsa: blue & $?$ \\
\hline Ciliates & 37.0 & Gills and pereiopods & MHE: basophilic macro and micronucleus & No \\
\hline Gregarine & 3.1 & Midgut & PAS+, Giemsa: blue & No \\
\hline Worms & 1.3 & Hemocoel & MHE: nuclei basophilic, cytoplasm eosinophilic & No \\
\hline
\end{tabular}

trophied with parasites (Fig. 4). Infections in epithelial cells of gut and hemocytes appeared to be of a focal nature, whereas infections in adipose cells were systemic (Fig. 4).

At least 5 fungi infected the amphipods. The yeastlike fungus measuring $2.2 \pm 0.2 \mu \mathrm{m}$ (width) $\times 5.0 \pm 6 \mu \mathrm{m}$ (length) had budding characteristics (Fig. 5). Fungus density and host response resulting in hemocytic nodules were so heavy in a few infections that some hemal spaces were occluded. Another yeast with needleshaped spores (Table 2) (range $=21.4$ to $25.6 \mu \mathrm{m}$ long $\times$ 1.6 to $3.3 \mu \mathrm{m}$ wide; $\mathrm{n}=16$, Fig. 6 ) had putative budding in smaller forms. The spores had interior refringent bodies that were arranged randomly as well as in rows. The amphipod heavily infected with a filamentous, branching, saprophytic-like fungus (Table 2) had many hemocytes with pyknotic nuclei and tissues that were slightly degenerate, indicating that the animal was either dead or moribund when collected. Additionally, one amphipod had a GMS+ coelozoic filamentous fungus-like organism within the lumen of gut ceca and another was found with epibiotic fungi infesting gills.

The sporoplasm of the haplosporidian (Table 2) measured $5.0 \pm 0.1 \mu \mathrm{m}$ long by $4.3 \pm 0.1 \mu \mathrm{m}$ wide $(n=21)$. When stained with AFB, certain stages of the spore had a prominent bar-shaped structure, which extended $1.3 \pm 0.1 \mu \mathrm{m}(\mathrm{n}=21)$ beyond the sporoplasm but was contained within the spore and may be a collapsed portion of the spore wall (Fig. 7). Developed spores had an external hinged cover or operculum (Fig. 8). Plasmodia in various stages of schizogony were observed throughout hemal sinuses (Fig. 9).

The microsporidian (Table 2) filled or replaced infected muscle tissues (Fig. 10). Spores, including immature ones, occurred in groups of 8 within the sporophorous vesicle, indicating that the species is a member of the Thelohaniidae. Morphological details were difficult to determine in histological sections, but spores measured $1.9 \pm 0.1 \mu \mathrm{m}$ long $\times 1.5 \pm 0.1 \mu \mathrm{m}$ wide (n = 40).

At least 3 species of ciliates were present on $37.0 \%$ of the amphipods (Table 2). One species was oval with an easily discernible macro- and micronucleus. Another morphologically distinct type was a stalked peritrich which was present on the gills and pereiopods either individually or in small groups (Fig. 11). The least prevalent type appeared integrally associated with host tissues and may have been internal.

A gregarine apicomplexan (Table 2) was observed as free within the midgut. The gregarine occurred in clusters or individually within ceca (Fig. 12). Some individuals in histological sections revealed a septum sep- 
arating the protomerite and deutomerite, indicating that the species is in the suborder Septatorina. Due to sectioning technique, sagittal sections of whole specimens were not obtained to provide accurate biometric data or complete morphological details.

Three worm species occurred in the hemocoel of the amphipods (Table 2). These were the spathebothriidean cestode (Acrobothriidae) Cyathocephalus truncatus (Fig. 13) and cystacanths of 2 acanthocephalan (Palaeacanthocephala, Echinorhynchidae) species, probably including Acanthocephalus dirus and Echinorhynchus salmonis.

Prevalence of nodules and ciliates varied significantly among individual sampling periods in the temporal assay, but there was no significant variation in prevalence of host response or parasites among years sampled (Table 3), season (Table 4), or before and after the introduction of the zebra mussel (Table 5). Among locations sampled, the prevalence of nodules, intranuclear basophilic bodies, a yeast-like organism, a haplosporidian, a microsporidian, ciliates, and gregarine and worm infections varied significantly. The prevalence of nodules and worms was significantly higher in amphipods from Lake Huron than from Lake Michigan (Table 6). The prevalence of the intranuclear basophilic bodies and the gregarine was significantly higher in northern Lake Michigan than in southern Lake Michigan (Table 7). There was no significant variation between these infections occurring in Grand Traverse Bay and the rest of Lake Michigan.

Table 3. Yearly prevalence of parasites in Diporeia spp. from Lakes Michigan and Huron, with number sampled, mean prevalence and ANOVA results among years sampled. There was no significant variation $(p<0.05)$ in prevalence among years

\begin{tabular}{|c|c|c|c|c|c|c|c|c|c|c|c|}
\hline Year & $\begin{array}{c}\text { No. } \\
\text { sampled }\end{array}$ & $\begin{array}{c}\text { Nodules } \\
(\%)\end{array}$ & $\begin{array}{l}\text { Intranuclear } \\
\text { body }(\%)\end{array}$ & $\begin{array}{l}\text { Rickettsia- } \\
\text { like (\%) }\end{array}$ & $\begin{array}{c}\text { Yeast and } \\
\text { yeast-like (\%) }\end{array}$ & $\begin{array}{c}\text { Fungi } \\
(\%)\end{array}$ & $\begin{array}{c}\text { Haplosporidian } \\
(\%)\end{array}$ & $\begin{array}{c}\text { Micro- } \\
\text { sporidian (\%) }\end{array}$ & $\begin{array}{c}\text { Ciliates } \\
(\%)\end{array}$ & $\begin{array}{c}\text { Gregarine } \\
(\%)\end{array}$ & $\begin{array}{l}\text { Worms } \\
(\%)\end{array}$ \\
\hline 1986 & 61 & 3.3 & 0.0 & 0.0 & 0.0 & 0.0 & 0.0 & 4.9 & 52.5 & 3.2 & 0.0 \\
\hline 1987 & 66 & 1.5 & 0.0 & 0.0 & 1.5 & 0.0 & 1.5 & 1.5 & 43.9 & 3.0 & 1.5 \\
\hline 1992 & 88 & 1.1 & 0.0 & 0.0 & 1.1 & 1.1 & 0.0 & 2.3 & 44.3 & 1.1 & 2.3 \\
\hline 1993 & 132 & 2.3 & 0.8 & 0.0 & 0.0 & 0.0 & 0.8 & 5.3 & 42.4 & 0.7 & 3.0 \\
\hline 1996 & 29 & 6.9 & 0.0 & 0.0 & 0.0 & 0.0 & 0.0 & 3.4 & 27.6 & 0.0 & 0.0 \\
\hline 1997 & 45 & 6.7 & 0.0 & 0.0 & 0.0 & 0.0 & 0.0 & 6.7 & 35.6 & 2.2 & 2.2 \\
\hline 1998 & 45 & 8.9 & 0.0 & 0.0 & 4.4 & 2.2 & 0.0 & 8.9 & 24.4 & 4.4 & 2.2 \\
\hline 1999 & 84 & 0.0 & 0.0 & 0.0 & 1.2 & 0.0 & 0.0 & 2.4 & 20.2 & 1.2 & 0.0 \\
\hline 2000 & 1165 & 8.8 & 0.3 & 2.3 & 1.5 & 0.3 & 0.0 & 3.6 & 36.6 & 3.7 & 1.2 \\
\hline Total & 1715 & mean 6.9 & 0.2 & 1.6 & 1.3 & 0.3 & 0.7 & 3.8 & 37.0 & 3.0 & 1.3 \\
\hline \multicolumn{2}{|c|}{ ANOVA $p=$} & 0.06 & 0.95 & 0.65 & 0.70 & 0.18 & 0.68 & 0.93 & 0.12 & 0.90 & 0.09 \\
\hline
\end{tabular}

Table 4. Seasonal prevalence of parasites in Diporeia spp. from Lakes Michigan and Huron, with number sampled, mean prevalence and ANOVA results among seasons. There was no significant variation $(\mathrm{p}<0.05)$ among seasons

\begin{tabular}{|c|c|c|c|c|c|c|c|c|c|c|c|}
\hline Season & $\begin{array}{c}\text { No. } \\
\text { sampled }\end{array}$ & $\begin{array}{c}\text { Nodules } \\
(\%)\end{array}$ & $\begin{array}{l}\text { Intranuclear } \\
\text { body }(\%)\end{array}$ & $\begin{array}{l}\text { Rickettsia- } \\
\text { like (\%) }\end{array}$ & $\begin{array}{c}\text { Yeast and } \\
\text { yeast-like (\%) }\end{array}$ & $\begin{array}{l}\text { Fungi } \\
(\%)\end{array}$ & $\begin{array}{c}\text { Haplosporidian } \\
(\%)\end{array}$ & $\begin{array}{c}\text { Micro- } \\
\text { sporidian (\%) }\end{array}$ & $\begin{array}{c}\text { Ciliates } \\
(\%)\end{array}$ & $\begin{array}{c}\text { Gregarine } \\
(\%)\end{array}$ & $\begin{array}{c}\text { Worms } \\
(\%)\end{array}$ \\
\hline Spring & 286 & 2.1 & 0.3 & 0.0 & 0.0 & 0.3 & 1.0 & 3.8 & 37.1 & 2.1 & 0.7 \\
\hline Summer & 1265 & 8.4 & 0.2 & 1.9 & 0.6 & 0.4 & 0.6 & 3.6 & 37.1 & 3.6 & 1.3 \\
\hline Autumn & 164 & 3.0 & 0.0 & 0.0 & 0.6 & 0.6 & 0.6 & 5.6 & 36.4 & 1.2 & 2.5 \\
\hline Total & 1715 & Mean 6.9 & 0.2 & 1.6 & 1.3 & 0.3 & 0.7 & 3.8 & 37.0 & 3.0 & 1.3 \\
\hline \multicolumn{2}{|c|}{ ANOVA $\mathrm{p}=$} & 0.19 & 0.87 & 0.35 & 0.62 & 0.17 & 0.68 & 0.98 & 0.12 & 0.23 & 0.97 \\
\hline
\end{tabular}

Table 5. Prevalence of parasites in Diporeia spp. from Lakes Michigan and Huron, with number sampled, mean prevalence and ANOVA results between samples taken before and after zebra mussel introduction. There was no significant variation $(p<0.05)$ between amphipods sampled before $(<)$ or after $(>)$ the introduction of zebra mussels

\begin{tabular}{|lcccccccccc|}
\hline Category & $\begin{array}{c}\text { No. } \\
\text { sampled }\end{array}$ & $\begin{array}{c}\text { Nodules } \\
(\%)\end{array}$ & $\begin{array}{c}\text { Intranuclear } \\
\text { body (\%) }\end{array}$ & $\begin{array}{c}\text { Rickettsia- } \\
\text { like (\%) }\end{array}$ & $\begin{array}{c}\text { Yeast and } \\
\text { yeast-like (\%) }\end{array}$ & $\begin{array}{c}\text { Fungi } \\
(\%)\end{array}$ & $\begin{array}{c}\text { Haplosporidian } \\
(\%)\end{array}$ & $\begin{array}{c}\text { Micro- } \\
\text { sporidian (\%) }\end{array}$ & $\begin{array}{c}\text { Ciliates } \\
(\%)\end{array}$ & $\begin{array}{c}\text { Gregarine Worms } \\
(\%)\end{array}$ \\
\hline < Mussels & 134 & 1.5 & 0.0 & 0.0 & 0.7 & 0.0 & 0.7 & 3.7 & 47.8 & 0.7 \\
> Mussels & 1581 & 7.3 & 0.2 & 1.7 & 1.4 & 0.4 & 0.7 & 0.7 \\
Total & 1715 & Mean 6.9 & 0.2 & 1.6 & 1.3 & 0.3 & 0.7 & 3.8 & 36.0 & 3.3 \\
ANOVA p & 0.09 & 0.62 & 0.29 & 0.75 & 0.58 & 0.75 & 1.4 \\
\hline
\end{tabular}




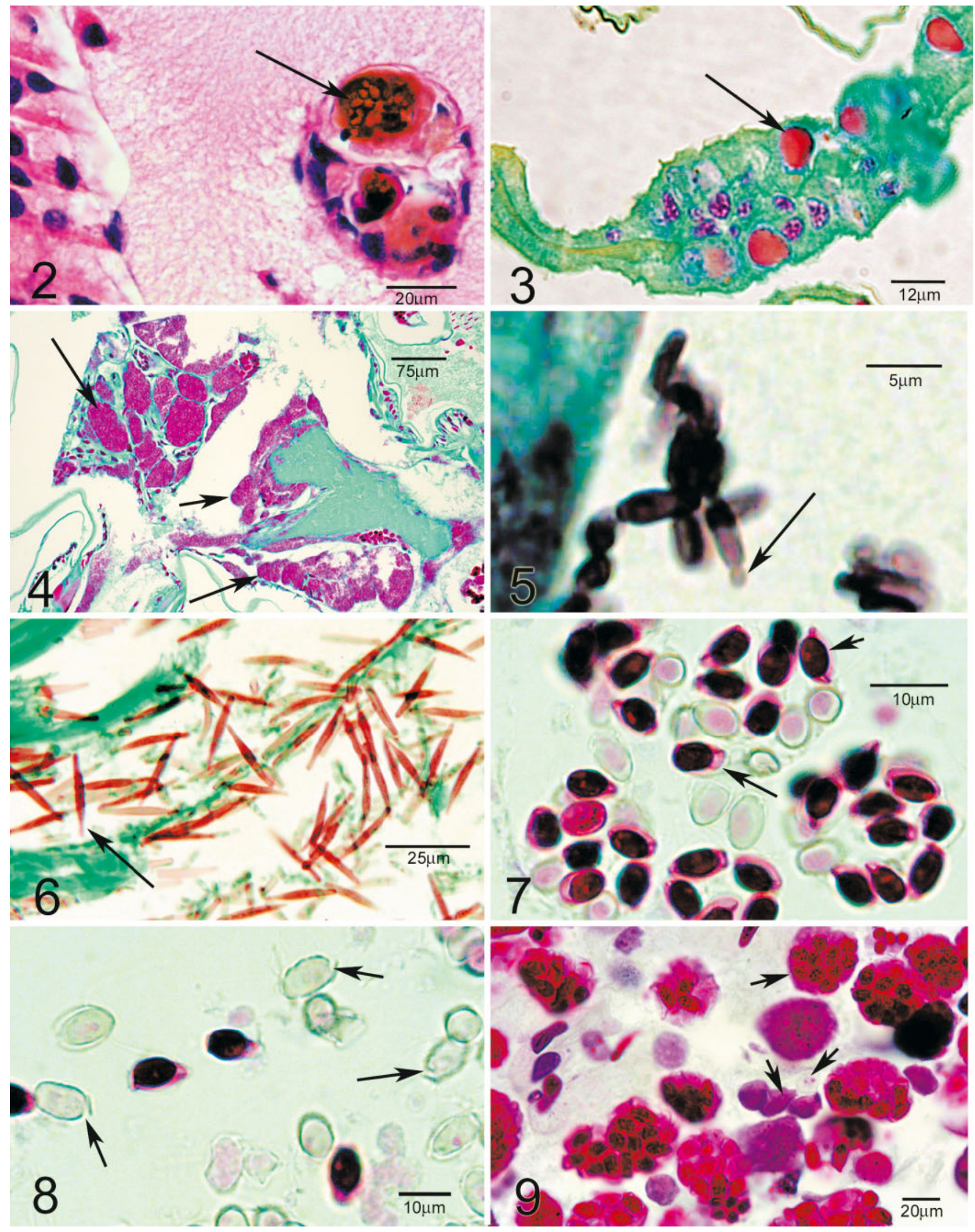




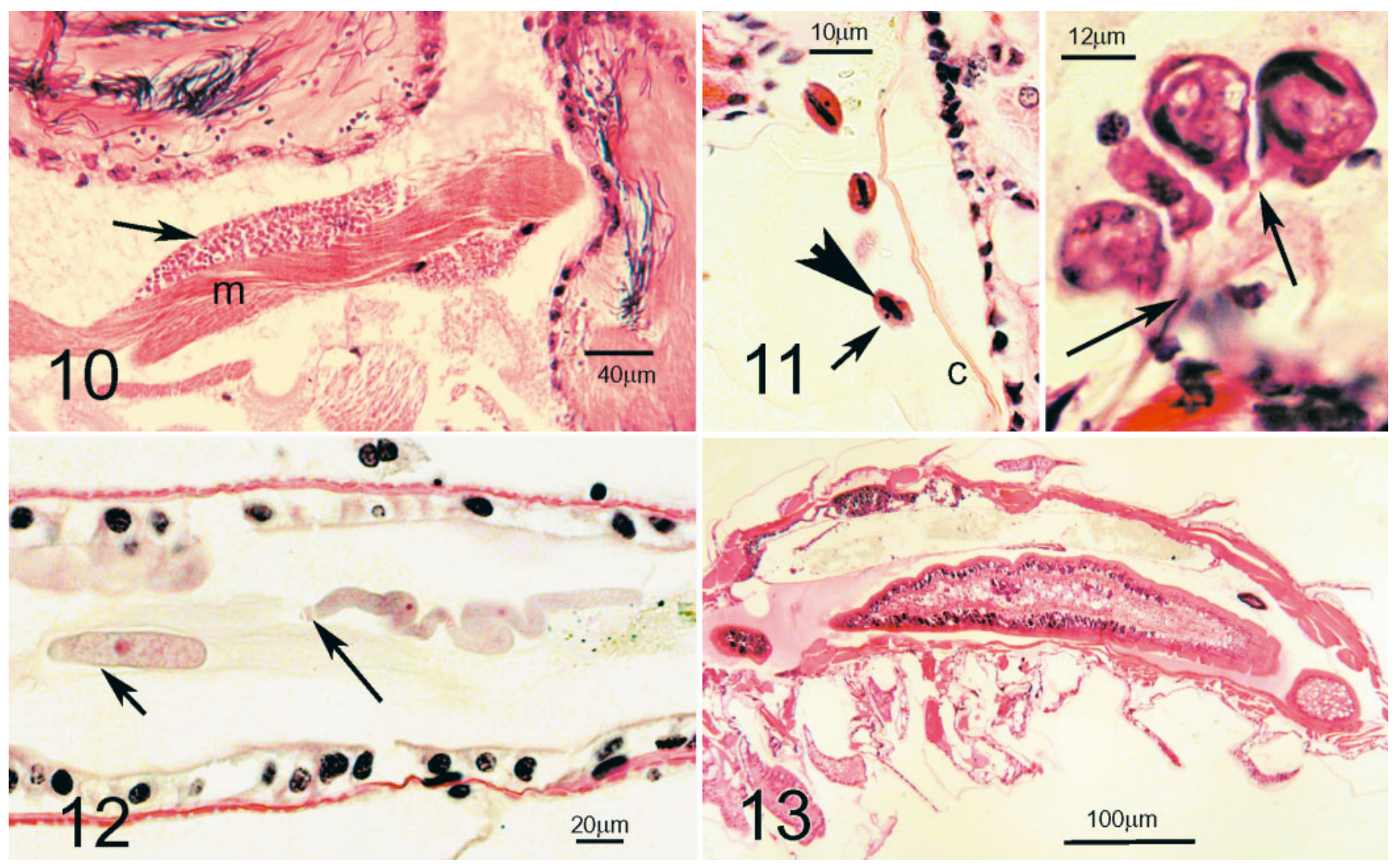

Figs. 2 to 13. Diporeia spp. Histological manifestations of parasites in the complex of Diporeia spp. from Lakes Michigan and Huron. Fig. 2. Differentiated host hemocytes encapsulating parasites (arrow) forming a hemocytic nodule within a hemal sinus of amphipod. Mayer's hematoxylin and eosin (MHE) stain. Fig. 3. Feulgen-positive large intranuclear bodies in epithelial cells of gill of amphipod causing cell hypertrophy. Note the thin rim of darker staining chromatic material (arrow). Feulgen picromethyl blue. Fig. 4. Masses of small intracellular granular rickettsia-like organisms within hypertrophied adipose cells throughout body of amphipod (arrows). Pierce Van der Kamp stain for rickettsia. Fig. 5. Clusters of a yeast-like fungus in a hemal sinus of amphipod. Note the budding characteristic (arrow). Grocott's methenamine silver stain for fungus. Fig. 6. A yeast with needle-shaped spores within muscle tissue (arrow) of amphipod. Grocott's methenamine silver stain for fungus. Fig. 7. Haplosporidian with prominent protrusions beyond sporoplasm but within spore (arrows) infecting amphipod. Acid-fast bacteria stain. Fig. 8. Haplosporidian with external hinged operculum (arrows) infecting amphipod. Acid-fast bacteria stain. Fig. 9. Plasmodia of haplosporidian in various stages of schizony (arrows) infecting amphipod. Acid-fast bacteria stain. Fig. 10. Microsporidian (arrow) filling or replacing skeletal muscle tissue $(\mathrm{m})$ of amphipod. MHE stain. Fig. 11. Unidentified ciliates among gills and pereiopods of amphipods; note the basophilic macronucleus (large arrow) and a smaller micronucleus (small arrow) in photo on left; $\mathrm{C}=$ host cuticle. Right photo: colonial peritrich ciliate attached to the host via a stalk (arrows). MHE stain. Fig. 12. Apicomplexan gregarine species free in lumen of digestive ceca of amphipod (arrows). Note the septum separating the protomerite and deutomerite (longer arrow). Heidenhain's hematoxylin. Fig. 13. Spathebothriidean cestode (Cyathocephalidae) Cyathocephalus truncatus within body cavity of a Diporeia spp. amphipod. MHE stain

Among the 7 depth categories, the prevalence of nodules, rickettsia-like organism, microsporidian and ciliates varied by depth. Nodules were significantly more prevalent at 51 to $75 \mathrm{~m}$ than at 26 to 50,76 to 100 and $>150 \mathrm{~m}$. Microsporidian infections were significantly more prevalent at $<25 \mathrm{~m}$ than at 26 to 50 or 51 to $75 \mathrm{~m}$ (Table 8). There was no clear relationship between depth and prevalence of any other infection.

\section{DISCUSSION}

Several different parasites infected samples of amphipod species of Diporeia from Lakes Michigan and Huron. This study documents the presence of several parasites not previously reported in Diporeia spp., although the worms found in this study have been reported in Diporeia spp. (e.g. Degiusti \& Budd 1959, Amin 1978). The scope of this paper is not to describe 
Table 6. Prevalence of parasites in Diporeia spp. from Lakes Michigan and Huron, with number sampled, mean prevalence and ANOVA results between lakes. $\mathrm{p} \leq 0.05=$ statistically significant variation

\begin{tabular}{|c|c|c|c|c|c|c|c|c|c|c|c|}
\hline Lake & $\begin{array}{c}\text { No. } \\
\text { sampled }\end{array}$ & $\begin{array}{c}\text { Nodules } \\
(\%)\end{array}$ & $\begin{array}{c}\text { Intranuclear } \\
\text { body }(\%)\end{array}$ & $\begin{array}{l}\text { Rickettsia- } \\
\text { like (\%) }\end{array}$ & $\begin{array}{c}\text { Yeast and } \\
\text { yeast-like (\%) }\end{array}$ & $\begin{array}{l}\text { Fungi } \\
(\%)\end{array}$ & $\begin{array}{c}\text { Haplosporidian } \\
(\%)\end{array}$ & $\begin{array}{c}\text { Micro- } \\
\text { sporidian(\%) }\end{array}$ & $\begin{array}{c}\text { Ciliates } \\
(\%)\end{array}$ & $\begin{array}{c}\text { Gregarine } \\
(\%)\end{array}$ & $\begin{array}{l}\text { Worms } \\
(\%)\end{array}$ \\
\hline Lake Michigan & 1519 & 6.4 & 0.3 & 1.4 & 1.3 & 0.3 & 0.7 & 3.6 & 37.1 & 3.0 & 1.1 \\
\hline Lake Huron & 196 & 10.7 & 0.0 & 3.1 & 1.5 & 1.0 & 1.0 & 5.6 & 35.7 & 4.1 & 3.1 \\
\hline Total & 1715 & Mean 6.9 & 0.2 & 1.6 & 1.3 & 0.3 & 0.7 & 3.8 & 37 & 3.1 & 1.3 \\
\hline ANOVA $\mathrm{p}=$ & & $0.0015^{\mathrm{a}}$ & 0.51 & 0.28 & 0.82 & 0.22 & 0.93 & 0.6 & 0.9 & 0.66 & $0.03^{\mathrm{b}}$ \\
\hline
\end{tabular}

Table 7. Prevalence of parasites in Diporeia spp. from northern Lake Michigan, southern Lake Michigan and Grand Traverse Bay in northern Lake Michigan, with number sampled, mean prevalence and ANOVA results among areas. $\mathrm{p} \leq 0.05=$ statistically significant variation

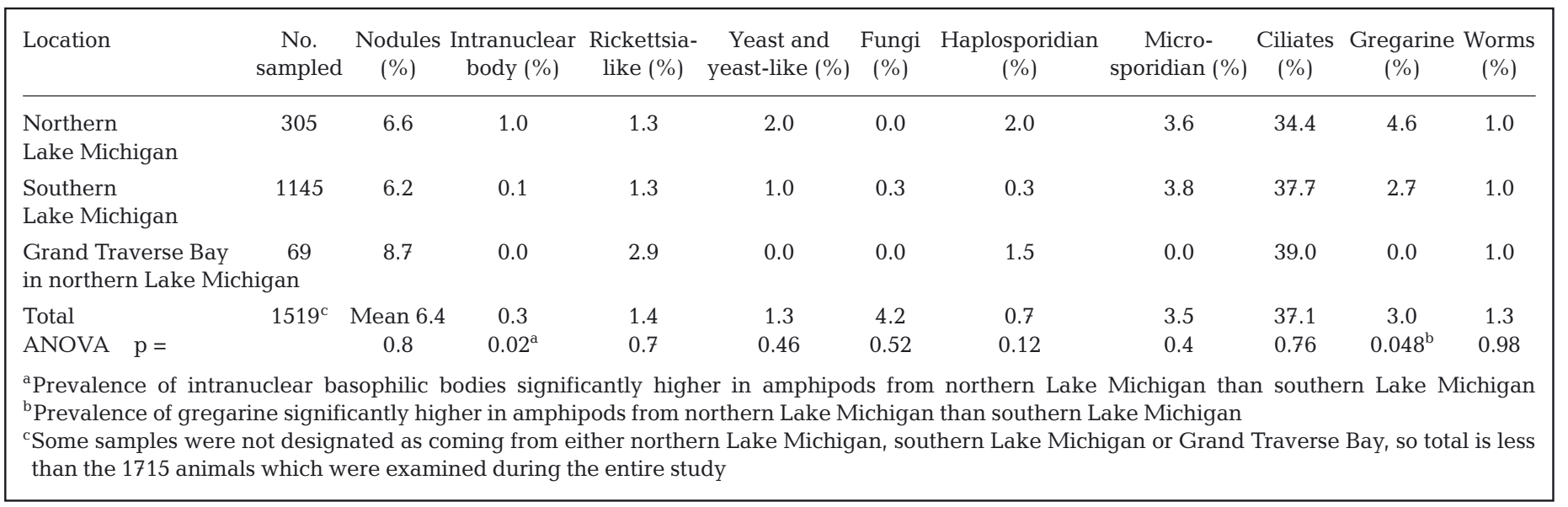

Table 8. Prevalence of parasites in Diporeia spp. collected from different depth categories of Lakes Michigan and Huron, with number sampled, mean prevalence and ANOVA results among depth categories. $\mathrm{p} \leq 0.05=$ statistically significant variation

\begin{tabular}{|c|c|c|c|c|c|c|c|c|c|c|c|}
\hline Depth (m) & $\begin{array}{l}\text { No. } \\
\text { sampled }\end{array}$ & $\begin{array}{c}\text { Nodules } \\
(\%)\end{array}$ & $\begin{array}{l}\text { Intranuclear } \\
\text { body }(\%)\end{array}$ & $\begin{array}{l}\text { Rickettsia- } \\
\text { like (\%) }\end{array}$ & $\begin{array}{c}\text { Yeast and } \\
\text { yeast-like (\%) }\end{array}$ & $\begin{array}{c}\text { Fungi } \\
(\%)\end{array}$ & $\begin{array}{c}\text { Haplosporidian } \\
(\%)\end{array}$ & $\begin{array}{c}\text { Micro- } \\
\text { sporidian (\%) }\end{array}$ & $\begin{array}{c}\text { Ciliates } \\
(\%)\end{array}$ & $\begin{array}{c}\text { Gregarine } \\
(\%)\end{array}$ & $\begin{array}{l}\text { Worms } \\
(\%)\end{array}$ \\
\hline$<25$ & 37 & 5.4 & 0.0 & 0.0 & 0.0 & 0.0 & 0.0 & 10.8 & 21.6 & 0.0 & 0.0 \\
\hline $26-50$ & 911 & $6.0^{\mathrm{a}}$ & 0.1 & 1.7 & 1.0 & 0.5 & 0.4 & 3.6 & 36.8 & 3.1 & 1.2 \\
\hline $51-75$ & 360 & $11.4^{\mathrm{b}}$ & 0.6 & 3.6 & 2.5 & 0.0 & 1.1 & 1.4 & 36.9 & 3.9 & 1.9 \\
\hline $76-100$ & 260 & 5.8 & 0.4 & 2.3 & 1.9 & 0.0 & 1.1 & $6.9^{\mathrm{c}}$ & 40.8 & 2.7 & 1.5 \\
\hline $101-125$ & 46 & 4.3 & 0.0 & 0.0 & 0.0 & 0.0 & 2.2 & 6.5 & 39.1 & 0.0 & 0.0 \\
\hline $126-150$ & 61 & 4.9 & 0.0 & 3.3 & 0.0 & 1.6 & 0.0 & 3.3 & 36.1 & 4.9 & 1.6 \\
\hline$>150$ & 40 & 0.0 & 0.0 & 0.0 & 0.0 & 0.0 & 0.0 & 5.0 & 30.0 & 2.5 & 0.0 \\
\hline Total & 1715 & Mean 6.9 & 0.2 & 1.6 & 1.3 & 0.3 & 0.7 & 3.8 & 37.0 & 3.1 & 1.3 \\
\hline ANOVA & $\mathrm{p}=$ & 0.005 & 0.61 & 0.33 & 0.42 & 0.21 & 0.32 & 0.007 & 0.93 & 0.57 & 0.73 \\
\hline
\end{tabular}

parasite species but to report the presence and prevalence of parasites in the amphipods surveyed.

Rickettsia-like infections have been reported in 3 amphipod species (Frederici et al. 1974, Larsson 1982, Graf 1984). Infection characteristics of rickettsia-like organism infections in Crangonyx floridanus (Frederici et al. 1974), and Rivulogammarus pulex (Larsson 1982) are similar to infections in adipose cells and hemocytes in this study. Epizootic mortalities in freshwater $C$. floridanus were caused by a rickettsia-like organism (Frederici et al. 1974); similar infections could have affected Great Lake amphipod numbers, if stressors 
were high enough (Johnson 1986). Although only $1.6 \%$ of the amphipods were infected in this study, infection prevalence was $2.3 \%$ in 2000 .

The yeast Cryptococcus gammari was reported as a pathogen in the amphipods Gammarus pulex and G. duebeni, infecting up to $50 \%$ of the individuals sampled from a stream near Oxford, England (Pixell Goodrich 1929). In these hosts, large numbers of spores apparently caused death by occluding the circulatory system. In chronic infections, those amphipods appeared speckled due to 'melanized' hemocytic encapsulations in response to the yeast. The declines of the amphipod Corophium volutator in 1929/1930 from Finland was attributed to C. gammari. Again, death was caused by the yeast blocking the circulatory system, and brownish or black spots often were observed on the legs and gills of specimens (Segerstrale 1937, 1960). In the present study, a few animals had dark spots on external surfaces and some animals with heavy yeast infections had 'melanized' nodules in tissues and partially occluded hemal sinuses, indicating that these yeast infections could cause mortalities.

Metschnikowia-type yeasts are similar in morphology to the organism found in a single amphipod from this study. Metschnikowia (Monospora) bicuspidata, characterized as having needle-shaped spores, caused mortalities within 2 wk in the laboratory-maintained cladoceran Daphnia magna (see Metchnikoff 1893). Metschnikowia-type yeasts have not been reported before in amphipods but Metschnikowia spp. have been reported in wild populations of D. magna, the anostracan Artemia salia (see Codreanu \& CodreanuBalcescu 1981), copepods Eurytemora velox, Calanus plumcrus (see Unestam 1973) and C. plumchrus (Seki \& Fulton 1969). Interestingly, Metschnikowia sp. was isolated from sporocysts of the parasitic diplostomoid digenean trematode Diplostomum flexicaudum inhabiting the digestive gland of the freshwater snail Lymnaea (Stagnicola) emarginata angulata from Douglas Lake in Michigan (Wickerham 1964). Perhaps other zooplankton or snail hosts in Lake Michigan are capable of transmitting the parasite to species of Diporeia and causing mortality.

There are few reports of haplosporidians infecting freshwater animals. One was found in amphipods from Louvain, Belgium (Ryckeghem 1930); it lacks an operculum and has been placed in the genus Claustrosporidium within the family Claustrosporidiidae (Larsson 1987). Another is Haplosporidium pickfordi, which was found in freshwater snails from the Douglas Lakes region of northern Michigan (Barrow 1961, 1965, Burreson 2001). The haplosporidian observed in Diporeia spp. in this survey has an operculum (Fig. 10), but additional study is needed to assess any ornamentation to identify the species, even to the generic level of
Haplosporidium or Minchinia (see Perkins 1991, 2000, Burreson 2001). The morphology of $H$. pickfordi is similar to the morphology of the haplosporidian observed in amphipods from this study (Barrow 1961, Burreson 2001).

Microsporidians are among the most common and serious pathogens affecting crustacean hosts (Sindermann 1971, Meyers 1990). Several have been reported in various amphipod species (e.g. Sprague 1970, 1977, Bulnheim 1975, Johnson 1985, Meyers 1990). Different microsporidians from amphipods are known to be transmitted orally and transovarially (Bulnheim 1975, Dunn \& Rigaud 1998), as well as through an intermediate host or under specific environmental or host conditions.

Numerous helminth species use crustaceans as their intermediate host (Jackson et al. 1997). Helminthinfected crustaceans frequently show altered behaviors such as increased motor activity, positive phototaxis and a greater propensity to drift in streams (Maynard et al. 1998), which can make them more susceptible to predation (Overstreet 1983, Bakker et al. 1997). The prevalence of amphipods infected with helminth species may have been higher than reported in this study due to this phenomenon, or infections may have been much more common in non-sampled specific habitats.

The present study did not assay for possible disease vectors, and we found no temporal variation in prevalence of parasites in relation to the introduction of zebra mussels. Although zebra mussels have greatly reduced the amount of food available to the amphipods, enough food was present to support at least a minimal population (Dermott 2001, Nalepa unpubl. data). Zebra mussels have been reported with rickettisia-like and chlamydia-like infections from Greece (Molloy et al. 2001), and a putatively lethal infection of a haplosporidian protozoan was reported in zebra mussels from The Netherlands (Bowmer \& Van der Meer 1991, Molloy et al. 1997). The relationship, if any, between parasite infections in the zebra mussel and amphipods is unknown. Exotic species such as zebra mussels can directly affect viability of native species through competition and habitat alteration (Nalepa et al. in press). They can also potentially pose an added threat if they harbor parasites and pathogens that infect native species, such as Diporeia spp. Lack of heritable genetic diversity within an endemic population could hamper its ability to quickly evolve a capable response to an exotic parasite, making the amphipod particularly vulnerable to extinction (Leberg \& Vrijenhoek 1994). Perhaps the decrease in Diporeia spp. populations in Lakes Michigan and Huron could have been influenced detrimentally by zebra mussels introducing a pathogen such as a rickettsia-like organism or haplosporidian. 
Parasitism is a principal biological force that controls zooplankton community structure (Yan \& Larsson 1988) and can substantially alter basic food-web properties (Marcogliese \& Cone 1997). Several studies of experimental and natural populations have shown that parasites can reduce host density and even induce extinction of host populations. Parasites can regulate host populations, some being more capable of doing so than others (see Ebert et al. 2000). Horizontally transmitted parasites that greatly reduce host survival and host fecundity are predicted to have low equilibrium prevalences of infection (Anderson \& May 1991, McCallum 1994). A study which compared the effects of various parasites, including microsporidian spp. and the fungus Metschnikowiella biscuspidata, on host fecundity and survival to their effects on density and risk of extinction of host Daphnia populations showed that in nature, the more virulent parasites were found in low prevalences, and that the most prevalent parasites were the ones that were found to be the least harmful to their hosts (Ebert et al. 2000). Ciliates, as a group, were by far the most prevalent infective agents found in our survey but, presumably, the least detrimental to the health of the amphipods, while the more virulent parasites such as a virus, a rickettsia-like organism, fungi, a haplosporidian, a microsporidianlike organism, and worms had relatively low prevalences. The reduced number of Diporeia spp. from Lakes Michigan and Huron may be explained by one or more virulent parasites driving Diporeia spp. and themselves to near extinction. Due to the inverse relationship between pathogenicity and prevalence of infection in host populations, some parasites can contribute significantly to host regulation, even though their actual prevalences remain low (Anderson \& May 1981).

Any form of stress, including thermal, can increase parasite-induced host mortality (Esch et al. 1975). Many parasites of aquatic organisms are sensitive to temperature change. Temperature affects the virulence of parasitic worms in fish (Marcogliese 2001), the survival and excystment of cercariae of digeneans in snails (Shostak \& Esch 1990) and the infectiveness of microsporidians (Overstreet 1990). Climate change due to global warming may affect parasite transmission and, potentially, virulence (Marcogliese 2001). Higher infection levels and parasite-induced mortality in the amphipod Corophium volutator were due to increasing temperature (Mouritsen \& Jensen 1997). This phenomenon was most likely governed by a similar temperature-dependent emergence of larval trematodes from first intermediate hosts, Hydrobia spp. snails (Shostak \& Esch 1990, Mouritsen \& Jensen 1997). With the prospect of global warming and climate change, we can expect some species to become locally extirpated and encounter range contractions, while introductions of other species, including potentially harmful pathogens, can be expected. Hostparasite systems are intricately interwoven with the environment (Marcogliese 2001).

The genus Diporeia consists of cold-water stenotherms, thus densities in nearshore areas of the Great Lakes are limited by the warmer water temperatures found in shallower areas above the thermocline. Recent trend analysis suggests that nearshore water temperatures in the Great Lakes are increasing (McCormick \& Fahnenstiel 1999), which may increase stress in Diporeia spp. and lead to increased susceptibility to parasites.

Other potential causes for the decline in Diporeia spp. populations that have been considered include food limitation, preference/avoidance response, fish predation, contaminants and oxygen deprivation (Nalepa et al. in press). Piscine population dynamics can have an effect on lower trophic levels such as zooplankton and amphipods. A study which examined the elimination of a normal piscine community with replacement by a planktivore-dominated fish assemblage on the diversity and abundance of the zooplankton community found that crustacean zooplankton species-composition remained unchanged, but the densities of various individual species decreased significantly (Marcogliese et al. 1992). Although past declines in Diporeia spp. were attributed to increased numbers of some species of fish, populations were never extirpated, and it is unlikely that predation pressure would systematically lead to a total loss of the amphipod population as presently observed (Nalepa et al. in press). Additionally, decreased food availability to Diporeia spp. due to Dreissena may have forced Diporeia spp. to more actively search for food and, thus, become more susceptible to predation (Lomnicki 1978). In a recent study, Diporeia spp. disappeared rapidly and completely in depositional regions where bottom substrates consisted of fine-grained materials (Nalepa et al. in press). The fine-grained particles are easily resuspended and, during storms, brief periods of reduced oxygen could occur in these regions of high deposition. Low oxygen levels at the sediment surface can affect the health and behavior of amphipods and even cause mortality (Eriksson \& Weeks 1994).

Many factors can decrease the rate of survival and, thus, population numbers in marine organisms. Microsporidosis by Thelohania contejeani, which was enhanced by increased lake acidity, is believed to have contributed to a reduction in annual crayfish Orconectes virilis survival rates in a glacially-formed precambrian Shield lake (France \& Graham 1985). That study found that neither lake acidification nor microsporidosis alone would have caused the reduction 
in survival rates, but that lake acidification exacted an additive mortality for crayfish populations and that microsporidosis exacerbated the decline of crayfish exposed to lake acidification before the level of toxicity, due to acidification, became directly toxic to the crayfish (France \& Graham 1985). It may be that interrelationships and dynamics of more than one physical or biological factor, such as high sedimentation, predation, food limitation, oxygen deprivation or virulent parasites, synergistically induced the decline in Diporeia spp. populations in Lakes Michigan and Huron.

Acknowledgements. We would like to acknowledge Dr. S. Galloway for encouraging this collaborative effort between the National Ocean Service Cooperative Oxford Laboratory and the Great Lakes Environmental Research Laboratory. We also thank Dr. S. Dumler of Johns Hopkins University; A. Farley, Cooperative Oxford Laboratory (retired); and Drs. J. Shields and E. Burreson, Virginia Institute of Marine Science, for assistance in identifying various parasites; J. Keller for editorial assistance; S. Hines for library materials; and the Environmental Protection Agency for use of the RV 'Lake Guardian' for sample collection. This is a contribution from USDA, CSREES Award No. 2002-38808-01381.

\section{LITERATURE CITED}

Amin OM (1978) On the crustacean hosts of larval acanthocephalan and cestode parasites in southwestern Lake Michigan. J Parasitol 64(5):842-845

Andersen AA (1998) Chlamydiosis. In: A laboratory manual for the isolation and identification of avian pathogens, 4th edn. Kendall/Hunt Publishing, Dubuque, IA

Anderson RM, May RM (1981) The population dynamics of microparasites and their invertebrate hosts. Phil Trans R Soc Lond B Biol Sci 291:451-424

Anderson RM, May RM (1991) Infectious diseases of humans. Oxford University Press, Oxford

Bakker TCM, Mazzi D, Zola S (1997) Parasite induced changes in behavior and color make Gammarus pulex more prone to fish predation. Ecology 78:1098-1104

Barrow JH (1961) Observations of a haplosporidian, Haplosporidium pickfordi sp. nov. in fresh water snails. Trans Am Microsc Soc 80:319-329

Barrow JH (1965) Observations on Minchinia pickfordae (Barrow 1961) found in snails of the Great Lakes region. Trans Am Micros Soc 84:587-593

Bowmer CT, Van der Meer M (1991) Reproduction and histopathological condition in first year zebra mussels (Dreissena polymorpha) from the Haringvliet, Volkerakmeer and Hollands Diep Basins, Delft, The Netherlands. TNO Inst Environ Sci Rep R 91/132, Delft

Bousfield EL (1989) Revised morphological relationships within the amphipod genera Pontoporeia and Gammaracanthus and the 'glacial relict' significance of their postglacial distributions. Can J Fish Aquat Sci 46:1714-1725

Brown RC, Hopps HC (1973) Staining of bacteria in tissue sections: a reliable Gram stain method. Am J Clin Pathol 59: $234-240$

Bulnheim HP (1975) Microsporidian infections of amphipods with special reference to host-parasite relationships: a review. Mar Fish Rev 37:39-45

Burreson EM (2001) Spore ornamentation of Haplosporidium pickfordi Barrow, 1961 (Haplosporidia), a parasite of freshwater snails in Michigan, USA. J Eukaryot Microbiol 48:622-626

Codreanu R, Codreanu-Balcescu D (1981) On two Metschnikowia yeast species producing hemocoelic infections in Daphnia magna and Artemia salina (Crustacea, Phyllopoda) from Romania. J Invertebr Pathol 37:22-27

Degiusti DL, Budd J (1959) A three-year survey of the infection rate of Echinorhynchus coregoni and Cyathocephalus truncates in their intermediate host Pontoporeia affinis from South Bay Mouth, Ontario. J Parasitol 45:25

Dermott R (2001) Sudden disappearance of the amphipod Diporeia from eastern Lake Ontario. J Gt Lakes Res 27: 423-433

Dermott R, Kerec D (1997) Changes to the deepwater benthos of eastern Lake Erie since the invasion of Dreissena: 1979-1993. Can J Fish Aquat Sci 54:922-930

Dunn AM, Rigaud T (1998) Horizontal transfer of parasitic sex ratio distorters between crustacean hosts. Parasitology 117:15-19

Ebert D, Lipsitch M, Mangin KL (2000) The effect of parasites on host population density and extinction: experimental epidemiology with Daphnia and six microparasites. Am Nat 156:459-477

Erriksson SP, Weeks JM (1994) Effects of copper and hypoxia on two populations of the benthic amphipod Corophium volutator (Pallas). Aquat Toxicol 29:73-81

Esch GW, Gibbons JW, Bourque JE (1975) An analysis of the relationship between stress and parasitism. Am Midl Nat 93:339-353

Farley CA (1969) Probable neoplastic disease of the hematopoietic system in oysters, Crassostrea virginica and Crassostrea gigas, neoplasms and related disorders of invertebrate and lower vertebrate animals. Natl Cancer Inst Monogr 31:541-555

France RL, Graham L (1985) Increased microsporidian parasitism of the crayfish Orconectes virilis in an experimentally acidified lake. Water Air Soil Pollut 26:129-136

Frederici BA, Hazard EI, Anthony DW (1974) Rickettsia-like organism causing disease in a crangonid amphipod from Florida. Appl Microbiol 28:885-886

Gardener WS, Quigley MA, Fahnenstiel GL, Scavia D, Frez WA (1990) Pontoporeia koyi-a direct trophic link between spring diatoms and fish in Lake Michigan. In: Tilzer MM, Serruya C (eds) Large lakes: ecological structures and functions. Springer-Verlag, New York, p 632-644

Graf F (1984) Presence de bacteries dans les caecums posterieurs de l'intestin moyen du Crustace hypoge Niphargus virei (Gammaridae: Amphipoda). Can J Zool 62:829-1833

Howard DW, Smith CS (1983) Histologic techniques for marine bivalve mollusks. NOAA Tech Mem NMFS-F/NEC 25:97, US Dept Commerce, Woods Hole, MA

Jackson CJ, Marcogliese DJ, Burt MDB (1997) Role of hyperbenthic crustaceans in the transmission of marine helminth parasites. Can J Fish Mar Sci 54:815-820

Johnson PT (1985) Parasites of benthic amphipods: microsporidans of Ampelisca agassizi (Judd) and some other gammarideans. US Fish Wildl Serv Fish Bull 83:497-505

Johnson PT (1986) Parasites of benthic amphipods: dinoflagellates (Duboscquodinida: Syndinidae). US Fish Wildl Serv Fish Bull 84:605-614

Larsson R (1982) A rickettsial pathogen of the amphipod Rivulogammarus pulex. J Invertebr Pathol 40:28-35

Larsson JIR (1987) On Haplosporidium gammari, a parasite of the amphipod Rivulogammarus pulex, and its relationship with the phylum Ascetospora. J Invertebr Pathol 49: 159-169 
Leberg PL, Vrijenhoek RC (1994) Variation among desert topminnows in their susceptibility to attack by exotic parasites. Conserv Biol 8:419-424

Lillie RD (1965) Histopathologic technic and practical histochemistry. McGraw-Hill, New York, p 715

Lomnicki A (1978) Individual differences between animals and the natural regulation of their numbers. J Anim Ecol 47:461-475

Lozano SJ, Scharold JV, Nalepa TF (2001) Recent declines in benthic macroinvertebrate densities in Lake Ontario. Can J Fish Aquat Sci 58:518-529

Luna LG (ed) (1968) Manual of histologic staining methods of the Armed Forces Institute of Pathology. McGraw-Hill, New York, p 258

Marcogliese DJ (2001) Implications of climate change for parasitism of animals in the aquatic environment. Can J Zool 79:1331-1352

Marcogliese DJ, Cone DK (1997) Food webs: a plea for parasites. Trends Ecol Evol 12:320-325

Marcogliese DJ, Esch GW, Dimock RV Jr (1992) Alterations in zooplankton community structure after selenium-induced replacement of a fish community: a natural whole-lake experiment. Hydrobiologia 242:19-32

Maynard BJ, Wellnitz TA, Zanini N, Wright WG, Dezfuli DS (1998) Parasite-altered behavior in a crustacean intermediate host: field and laboratory studies. J Parasitol 84: 1102-1106

McCallum H (1994) Quantifying the impact of disease on threatened species. Pac Conserv Biol 1:107-117

McCormick MJ, Fahnenstiel GL (1999) Recent climatic trends in nearshore water temperatures in the St. Lawrence Great Lakes. Limnol Oceanogr 44:530-540

Metchnikoff E (1893) Lectures on the comparative pathology of inflammation. Kegan Paul, Trench, Trübner \& Co, London, p 218

Meyers TR (1990) Diseases caused by protistans and metazoans. In: Kinne O (ed) Diseases of marine animals. Biologische Anstalt Helgoland, Hamburg, p 350-423

Molloy DP, Karatayev AY, Burlakova LE, Kurandina DP, Laruelle F (1997) Natural enemies of zebra mussels: predatory, parasites, and ecological competitors. Rev Fish Sci 5:27-97

Molloy DP, Giamberini L, Morado JF, Fokin SI, Laruelle F (2001) Characterization of intracytoplasmic prokaryote infections in Dreissena sp. (Bivalvia: Dreissenidae). Dis Aquat Org 44:203-216

Mouritsen KN, Jensen KT (1997) Parasite transmission between soft-bottom invertebrates: temperature mediated infection rates and mortality in Corophium volutator. Mar Ecol Prog Ser 151:123-134

Nalepa TF, Hartson DJ, Fanslow DL, Lang GA, Lozano SJ (1998) Decline in benthic macroinvertebrate populations in southern Lake Michigan, 1980-1993. Can J Fish Aquat Sci 55:2401-2413

Nalepa TF, Hartson DJ, Buchannan J, Cavaletto JF, Lang GA, Lozano SJ (2000) Spatial variation in density, mean size, and physiological condition of the holarctic amphipod Diporeia spp. in Lake Michigan. Freshw Biol 43:107-119

Nalepa TF, Fanslow DL, Messick GA (in press) Characteristics and potential causes of declining Diporeia populations in southern Lake Michigan and Saginaw Bay, Lake

Editorial responsibility: Timothy Flegel,

Bangkok, Thailand
Huron. Proceedings of Lake Whitefish - Diporeia Workshop, Great Lakes Fish Comm Tech Rep 66, Ann Arbor, MI

Overstreet RM (1983) Metazoan symbionts of crustaceans. In: Bliss DE, Provenzano AJ (eds) The biology of Crustacea. Academic Press, New York, p 155-250

Overstreet RM (1990) Antipodean aquaculture agents. In: Boreham PFL, Boreham RE (eds) Proceedings of the silver jubilee scientific and general meeting of the Australian Society for Parasitology. Int J Parasitol 20:551-564

Perkins FO (1991) Sporozoa: Apicomplexa, Microsporidia, Haplosporidia, Paramyxea, Myxosporidia, and Actinosporidia. In: Harrison FW, Corliss JO (eds) Microscopic anatomy of invertebrates. Wiley-Liss, New York, p 261-331

Perkins FO (2000) Phylum Haplosporidia Caullery and Mesnil, 1899. In: Lee JJ, Leedale GF, Bradbury P (eds) Illustrated guide to the protozoa, second edition: organisms traditionally referred to as Protozoa, or newly discovered groups. Society of Protozoologists, Lawrence, KA, p 1328-1341

Pixell Goodrich HL (1929) Reactions of Gammarus to injury and disease with notes on some microsporidial and fungoidal diseases. Quart J Microsc Sci 72:325-353

Pothoven SA, Nalepa TF, Schneeberger PJ, Brandt SB (2001) Changes in diet and body condition of lake whitefish in southern Lake Michigan associated with changes in benthos. N Am J Fish Manag 21:876-883

Ryckeghem J (1930) Les cnidosporidies et autres parasites de Gammarus pulex. Cellule 39:399-418

SAS (1999) Using Statview. SAS Institute, Cary, NC, p 288

Segerstrale SG (1937) Studien über die Bodentierwelt in südfinnländischen Küstengewässern. IV. Bestandesschwankungen beim amphipoden Corophium volutator. Acta Soc Fauna Flora Fenn 60:245-255

Segerstrale SG (1960) Fluctuations in the abundance of benthic animals in the Baltic area. Commentat Biol Soc Sci Fenn 23:2-19

Seki H, Fulton J (1969) Infection of marine copepods by Metschnikowia sp. Mycopathol Mycol Appl 38:61-70

Sindermann CJ (1971) Internal defenses of Crustacea: a review. US Fish Wildl Serv Fish Bull 69:455-489

Shostak AW, Esch GW (1990) Temperature effects on survival and excystment of the cercariae of Halipegus occidualis (Trematoda). Int J Parasitol 20:95-99

Sprague V (1970) Some protozoan parasites and hyperparasites in marine decapod Crustacea. In: Snieszko SF (ed) A symposium on diseases of fishes and shellfishes. Am Fish Soc Spec Publ, 5 Bethesda, MD, p 416-430

Sprague V (1977) Classification and phylogeny of the Microsporidia. In: Bulla LA, Cheng TC (eds) Comparative pathobiology: treatises Vol. 2, Systematics of the Microsporidia. Plenum Press, New York, p 1-30

Unestam T (1973) Fungal diseases of Crustacea. Rev Med Vet Mycol 8:1-20

Wickerham LJ (1964) A preliminary report on a perfect family of exclusively proto-sexual yeasts. Mycologia 56:253-266

Yan ND, Larsson JIR (1988) Prevalence and inferred effects of microsporidia of Halopedium gibberum (Crustacea: Cladocera) in a Canadian Shield lake. J Plankton Res 10: 875-886

Submitted: February 24, 2003; Accepted: November 17, 2003 Proofs received from author(s): April 15, 2004 